\title{
Can Art Make a Difference? Visual and Performative Arts on the Indonesian Mass Killings of 1965-66
}

\author{
Michał Bielecki
}

\begin{abstract}
This paper considers the impact of various activities of artistic nature in public debate and collective memory of the genocide in Indonesia in the years 1965-1966, as well as the public reception of these event, with a particular focus on Joshua Oppenheimer's documentary „The Act of Killing” (2012). As a result of systematic extermination of PKI members and sympathizers, between 500 thousand and 2 million people were killed. These murders are often considered an 'unspoken' or 'forgotten' crime. In Suharto's Indonesia, questioning the official version of events was prohibited. In 1998, General Suharto resigned from office and the state begun a slow drift towards democracy. The issue of the traumatic past, however, remains a very uncomfortable one. The crime of such scale cannot be easily forced into oblivion. The pressure faced by authorities in today's Indonesia was caused partly, if not mainly, by mnemonic actors of an artistic nature, by both Indonesian and foreign artists interested in this matter. By applying content analysis, the proposed paper discusses varied artistic activities addressing the mass violence and their influence on the public discussion and the collective memory of that event. Content analysis of media reports, interviews with artists, fictional and documentary films was carried out by the author. The study shows how art contributes to the process of dealing with Indonesia's past
\end{abstract}

Keywords: Indonesia, Film, PKI, Memory, Visual art, 1965

\footnotetext{
1 Graduate School for Social Research, Institute of Philosophy and Sociology, Polish Academy of Sciences, Warsaw, Poland and Center for Southeast Asian Social Studies, Universitas Gadjah Mada, Yogyakarta, Indonesia. Coressponding e-mail: michal.bielecki@wp.pl
} 


\section{Introduction}

On the night between 30 September and 1 October 1965, a coup took place in Indonesia. A group of mid-ranking Indonesian military officers kidnapped and soon killed six high-ranking generals. On 1 October, they published a series of statements aired by the state-controlled radio station Radio Republik Indonesia (Radio of the Indonesian Republic). In these statements, the group declared itself the "Revolutionary Council" and announced that it was taking over power in the country to prevent a coup planned by right-wing generals backed by the United States. Their plan was foiled by the then little-known General Suharto, who arrived at the site of the unfolding events, arrested all of those involved in the abduction, and claimed real power in the country.

Then-president Sukarno was placed under house arrest at his residence in Jakarta, officially for security reasons. The blame for the coup was placed squarely on the shoulders of the Indonesian Communist Party (Partai Komunis Indonesia, PKI), then - with almost 3.5 million members - the largest communist party in the noncommunist world (Mortimer, 2006, p. 366). Rumours of the communists' inhumane brutality and plans to create a secular state spread like wildfire in Indonesia, as did stories of the brave general Suharto, who was said to have saved the country from the greatest disaster it had faced since independence.

A few days after the 30 September Movement's coup, General Suharto took over the real power in Indonesia and initiated the extermination of PKI members. Suharto, through a formal order signed on 15 November 1965, ordered that "all [PKI] followers and sympathizers should be eliminated" and ordered the extermination of the party "down to its very roots" (Brackman, 1969, pp. 118-119, as cited in Gallately \& Kierman, 2003, p. 46). This period of Indonesian history has become known as Musim Potong - the carnage time (Bonczol, 2012, p. 122). About five hundred thousand people were killed within a few months. However, the exact figure remains unknown, and estimates reach as high as two million victims (Cribb, 2004, p. 239).2 Approximately a million people were arrested and subjected to torture over the next decade (Wandita, 2014, p. 168). The perpetrators of these

\footnotetext{
2 More on this subject: R. Cribb, "How Many Deaths? Problems in the Statistics of Massacre in Indonesia (1965-1966) and East Timor (1975-1980)", in I. Wessel, G. Wimhoefer, (ed.), Violence in Indonesia, Hamburg, Abera, 2001, pp. 82-98.
} 
attacks were special squadrons of the Indonesian army, civil militias trained for that purpose, and local gangsters. The anti-communist witch-hunt was often exploited for resolving personal conflicts. Apart from PKI members, their families, as well as ethnic Chinese and persons suspected of communist sympathize, were also targeted.

\section{The New Order, CIA, and the Killing}

The killing was systematic violence that became the foundation of General Suharto's "Orde Baru" (New Order), a regime that lasted for over thirty years. ${ }^{3}$ The scale of the events is described in a fragment of a Central Intelligence Agency (CIA) internal analysis from 1968:

"We do not know - and will never know - a reliable number of people killed as a result of the Indonesian revolution. Without a doubt, however, it was huge. Killings on Java alone overshadow the Mau Mau massacre and the Congo genocide, although the latter caught much more attention. In terms of the number of the murdered, the anti-communist massacres in Indonesia are among the greatest mass murders in the $20^{\text {th }}$ century - such as the Soviet purges in the thirties, the Nazi mass murders during the Second World War, and the bloodbath initiated by Mao in the fifties. In this respect, the coup in Indonesia is one of the most important events of the twentieth century, far more important than some of the tragedies that gained greater notoriety" (Indonesia - 1965: The Coup..., 1968, p. 71. as cited in Bonczol, 2012, p. 123). ${ }^{4}$

The killings began a few days after the 30 September Coup in parts of eastern Java and in the conservative Muslim areas of northern Sumatra (mainly Aceh). In those regions, local religious leaders took the killing initiative. Other parts of the archipelago followed soon after, though murders did not usually start until the army 'anti-communist forces' came.

Regular mass executions began in the second half of October and lasted until mid-March 1966. Carnage spread mostly through villages, with the military playing a major role in arming and training anti-communist vigilantes. At times, the knowledge that the killing was sanctioned by the army kicked the genocidal machine into motion.

Murders were conducted in a variety of ways. Accused communists were often driven out of their home villages and killed, their bodies dumped in rivers, thrown

\footnotetext{
${ }^{3}$ Gen. Suharto ruled Indonesia continuously up to 1998.

${ }^{4}$ All quotations from non-English sources have been translated by the author.
} 
into caves, burned, or tossed into the sea. Their corpses were frequently mutilated, arguably in revenge for the desecration of the bodies of the captured generals but also to make identifying the victims more difficult. These actions may also have been the result of local beliefs that mutilated bodies cannot return to Earth (Cribb, 2004). Benedict Anderson (1988) discusses the subject in The Spectre of Comparisons: Nationalism Southeast Asia and the World, describing an unbearable stench floating over villages, rivers filled with bamboo poles covered in human guts, victims' genitals hanging on the fences of local brothels, and headless corpses lining the river banks. Such atrocities only heightened the omnipresent fear.

For a multitude of reasons, these murders are often considered 'unspoken' or 'forgotten' crimes. In Suharto's Indonesia, questioning the official version of events was, understandably, prohibited. Although the fates of suspected PKI members and supporters made were reported in world media, the international community remained passive. Suharto was, at the time, positively characterised by American media, ${ }^{5}$ which focused on his promotion of "stability" and "growth". As Herman and Chomsky (1988) put it, in the eyes of the American press Suharto was "a good genocidist" (p. XL) compared to totalitarian leaders such as Pol Pot or Castro.

The Indonesian dictator was never described as "crazed" or "blood-soaked", or as a "killer", "mass murderer", or "war criminal" (p. XXXVIII) - all terms commonly used to describe the Cambodian dictator. In a world overcome by Cold War, political interests seemingly proved more important than the lives of hundreds of thousands of innocent people. Furthermore, Western powers, while fully aware of the killings raging in Indonesia, granted the new regime substantial financial support in the form of Central Bank and International Monetary Fund grants (Bonczol, 2012). Recently declassified CIA documents concerning anti-communist violence in Indonesia prove that the United States had detailed knowledge of what was happening in Indonesia. ${ }^{6}$

\section{Art and the Forgotten Past}

The exact origin of events is still unclear, and many questions have yet to be answered. However, the view that the PKI participated in the coup has been challenged repeatedly. Cribb (2004) suggests that, if the communists were

\footnotetext{
${ }^{5}$ For more information on the global context of this, see Baskara T. Wardaya (2001).

6 For more information, see: https://nsarchive.gwu.edu/briefing-book/indonesia/2017-1017/indonesia-mass-murder-1965-us-embassy-files
} 
associated with the kidnappers, it was only a few people from the party's leadership; the rest of its members were not privy to the course of events. The previously mentioned CIA documents likewise indicate that the PKI's participation in the 30 September Movement was unlikely. ${ }^{7}$

In shaping collective memories of these events and popularising the version propagated by the regime, the art of film became a vital tool. Suharto realized that, with proper supervision, cinematography can be of great help in shaping the consciousness of the masses. In 1984, a propaganda feature film titled Pengkhianatan G30S/PKI ('The Treachery of the G30S/PKI) was produced. The picture, directed by Arifin C. Noer, is monumental, executed finely in terms of workshop and form. Its message is simple, yet extremely suggestive: savage communists are guilty of treason, cruelty, and brutal murder, and their irrepressible desire to seize power and exact revenge threatens not only the elites, but also ordinary Indonesians. General Suharto, presented as a patriot and defender of Indonesia's fundamental values, prevents the country's undoing with his heroic act. In light of the events portrayed on screen, the drastic solution to the problem of the PKI and its supporters undertaken afterwards seems reasonable.

The authorities ensured that the film reached the largest possible audience. It was shown annually on the anniversary of the coup for fourteen years, both on state television and in public institutions, schools and universities. According to a survey of Indonesian high school students conducted by Tempo magazine in 2001, the film had been seen by 97 per cent of people surveyed, and the vast majority had seen it multiple times (Heryanto, 2005). For many decades, Pengkhianatan G30S/PKI - a mnemonic manipulation on a huge scale - was a key tool for shaping Indonesians' attitudes and collective memories of the events in question.

In 1998, in the face of a devastating financial crisis, General Suharto resigned from office and the state began its slow drift towards democracy. The issue of the genocide experienced by Indonesian communists, however, remained and has remained very uncomfortable. The new authorities seem in no rush to solve the problem, recognise the systemic character of the murders, bury the dead with dignity, commemorate the victims, apologise, or, last but not least, punish the guilty.

\footnotetext{
7 More on various theories regarding the origins of the 30. September Movement can be found, among other publications, in: Roosa, J. (2006). Pretext for Mass Murder. The September 30th Movement and Suharto's Coup d'État in Indonesia, Madison: The University of Wisconsin Press.
} 
The influence of those indirectly involved in the genocide, as well as those supporting Suharto's Orde Baru regime, does not seem to be diminishing. The current president of Indonesia, Joko Widodo, has not taken any significant action in this case either, despite mounting pressure from the National Commission on Human Rights (Komnas HAM), Research Foundation on the Victims of 65 Killing (Yayasan Penelitian Korban Pembunuhan 65, YPKP 65) the National Commission on Violence against Women (Komnas Perempuan), and other organizations.

The issue of genocide, however, cannot easily be forced into oblivion, where it has remained for the past decades. The pressure faced by authorities in today's Indonesia is caused partly by mnemonic actors, i.e. both Indonesian and foreign artists interested in this matter. The turning point in uncovering this 'forgotten' crime, and thus one of the starting points in the process of deconstruction of official memory regime, was the documentary The Act of Killing (2012) by American director Joshua Oppenheimer. The film, which will be discussed later in more detail, gained unprecedented publicity around the world. It is difficult to say how many people have seen it in Indonesia, as it was not officially distributed. However, it has certainly boosted public discussion of the topic in Indonesia and abroad.

Nevertheless, attention should first be drawn to the activities of Papermoon Puppet Theatre in Yogyakarta (a city considered the cultural centre of Java), which has staged several plays about the events of 1965. The first, Noda Lelaki di Dada Mona ('The Man's Stain on Mona's Breast') was performed in 2008, with the genocide merely a backdrop for the events unfolding in the play. Another performance - Mwathirika ('Victims', 2010) - centres around genocide. It tells the story of two families living in the same neighbourhood. Ten-year-old Moyo and fouryear-old Tupu are left home alone, after their father, Baba, is accused of belonging to the PKI and taken away. Their neighbour, Haki, not only fails to assist the abandoned children, but forbids his daughter Lacuna from playing with them. He fears that she may also be in danger, and, as we learn in the last scene of the play, these fears are not unfounded. That moving performance became one of the first widely commented upon voice of artists regarding this matter. Besides Yogyakarta, the play was shown in Jakarta, as well as internationally in the United States, Singapore, and Australia. The story was written based on interviews - conducted by members of the 
Papermoon Puppet Theatre themselves - with relatives of victims, as well as those who survived but spent decades in prison camps for former communists.

A true story also became the inspiration for the group's next play, Setjangkir Kopi dari Playa ('A Cup of Coffee from Playa', 2011). The main character, Widodo, moves to Yogyakarta to study. In 1960, he is awarded a scholarship for outstanding achievements in science that allows him to study in Moscow. Before leaving, he proposes to his girlfriend. In October 1965, he is still in Moscow, and like all Indonesians studying in the countries of the Eastern Bloc, is branded a Communist and stripped of Indonesian citizenship. Over the years, Widodo tried unsuccessfully to contact his fiancée. When he finally returns - people in such a situation were only permitted to return to Indonesia at the beginning of the twenty-first century - it becomes clear that the relationship cannot continue. Too much has changed over time. 89

Although all performances by Papermoon Puppet Theatre enjoyed excellent turnout, the impact of a play can hardly be compared with that of a film. This is evidenced by the case of Joshua Oppenheimer, whose aforementioned documentary The Act of Killing received dozens of awards at major film festivals, from Berlin to Venice to London, and was nominated to receive an Academy Award. The publicity generated by his film was an important step in restoring the memory of past events.

Oppenheimer finds out about the genocide by accident, while filming a different documentary in Sumatra. He decides to explore the topic. First, he interviews relatives of the victims. However, they are usually reluctant to talk; they are either afraid, or simply do not know much. It turns out, though, that the perpetrators, who were often the victims' neighbours, are much more open to conversation. When asked why he decided to talk to them, Oppenheimer explains:

"One of the female plantation workers suggested that to me [...]. She said that the killers will be eager to talk about the genocide, because they are proud of what they did, they are proud of their achievements in the fight against communism. She advised me to go to a neighbour of hers, who killed her aunt. He worked as a guard on the plantation and was promoted to manager for his

\footnotetext{
8 Paragraph based on: Lis, M. (2015). Rok 1965 w Indonezji w spektaklach Papermoon Puppet Theatre z Yogyakarty i filmie Scena zbrodni Joshuy Oppenheimera [1965 in Indonesia in Papermoon Puppet Theater's performances and The Act of Killing film by Joshua Oppenheimer], Studia Azjatystyczne, 1, pp. 64-76.

9 For more on Papermoon Puppet Theatre, visit the group's official website: www.papermoonpuppet.com
} 
achievements in eliminating trade union members in 1965. I loitered a bit in front of his house with a camera, pretending to be filming the area and he invited me to tea. In less than half an hour he started talking in detail about how he was catching people by the legs and smashing their heads with a kick. While he was talking about that, his ten-year-old granddaughter was sitting at the table. She looked bored, because she probably had heard it plenty of times already" (Oppenheimer, 2013).

The central character of The Act of Killing is Anwar, who, in the 1960s, was a young gangster fascinated by American gangster cinema films. His ideas of how to kill stemmed mostly from films he saw at the local cinema, where he also often made extra money by selling tickets for screenings at a higher price. At one of his meetings with Oppenheimer, Anwar offered to show the director locations where he committed the murders. At some point, the gangster and his friend begin to act out scenes, with Anwar playing himself as he was at the time. The idea to create a feature film, in which the torturers would play themselves, was born. The Act of Killing is a record of preparations for this film within a film; however, it also features entire scenes played out and co-directed by Anwar and his colleagues.

Due to censorship, the film was not distributed in Indonesia. However, it was available online, legally and free of charge, throughout the archipelago. Oppenheimer often treats the film as a tool for changing public perceptions in Indonesia and around the world. He also attempts to shape a new collective memory of those events through cooperation with non-governmental organizations interested in dealing with the painful past. The director emphasises not only the importance of Indonesia returning to these 'unspoken' and 'forgotten' crimes, but also the urgency of Western powers accepting responsibility.

Criticism of The Act of Killing generally relates to two aspects of the film. First is the formal side, in most cases described in superlatives. Even those who expressed reservations have praised the innovative approach and tremendous power of the film's artistic expression. However, as a documentary telling the story of such dramatic events, it has been criticised in terms of its integrity when presenting a certain vision of the world, as well as the ethical implications of its distribution.

Dwyer (2014), in an article titled "Picturing Violence: Anti-Politics and The Act of Killing", expresses some doubt as to the ethical side of the project. As she stresses, it is not the frequent, but fairly superficial, doubt about paying former killers as they become members of the film crew. Much more crucial is analysis of how the film can 
be read by the public. Dwyer brings up the director's remarks, in which he suggests that his film first opened a space for Indonesians to talk about what happened in their country nearly half a century ago. She challenges this claim, pointing to the various activities already undertaken by Indonesian activists and non-governmental organizations that had initiated discourse on this topic. As such, Dwyer suggests, it is an oversimplification (and maybe even arrogance) to state that The Act of Killing broke the silence or stopped the massacres from being entirely forgotten. It is not true that Indonesians had waited 47 years for an American director, 'a saviour', to show them their own bloody past and weakness in the face of pervasive violence and impunity. Dwyer cites in this context colonial historiography, in which opposition is based on the notion of 'our' civilised enlightenment versus 'their' barbarism. In this sense, Oppenheimer's goal of revealing shocking and still unpunished crimes as an external observer becomes part of an old, racist narrative that objectifies Indonesian society.

Oppenheimer was also criticised for the lack of a clear and specific historical narrative in The Act of Killing, without which a true and comprehensive picture of the 1965-1966 massacres could be misunderstood by the public. Cribb (2013), among others, feared that Oppenheimer's film may be (for those unfamiliar with the topic) "deeply misleading" because it does not present the overall context of how the mass murders were organized. According to Cribb, the film presents the massacre as an act carried out by civilian gangsters rather than as a nationwide action executed by the army and supervised by the Suharto regime. As such, the movie maintains a false picture of "barbaric Indonesians" who spontaneously began violent purges against communists.

Without a doubt, Cribb has broad and in-depth knowledge of Indonesian history, whereas any standard-length film can only present a narrow range of reality. There is, however, a fundamental difference between situations in which authors focus on certain aspects of a case and treat others marginally and situations in which authors are guilty of omission or even suggesting false versions of events. This criticism was also refuted by Jacqui Baker (2014), who indicated that The Act of Killing was not intended to be a conventional documentary, which recalls and creates a ready and comprehensive narrative of events. She also points out that the film's 
lack of a clear historical narrative should not in any way be identified as disregard for the regime's role in organizing the mass killings.

Cribb (2013) also alleges that the director did not, in any way, try to verify the stories of Anwar Congo and his colleagues. Cribb's doubts were not about whether they were actually enforcers, but whether the huge number of deaths they boast about are exaggerated. In his review, there is one more very serious allegation. Cribb (2013) writes:

“(...) By this time in the film, Oppenheimer has made clear that Congo regarded him as a friend. Did Oppenheimer really just keep the cameras running and maintain his distance while his friend was in distress? Did Congo really think nothing of vomiting in front of the camera, under studio lights, and walking away as if the camera were not there? The incident seems staged".

Cribb is therefore suggesting serious manipulation on the part of the director. It seems too hasty a conclusion to assume that, as Anwar seems to treat Oppenheimer as a friend, the director would treat him the same. When asked in interviews, Oppenheimer said about the relationship that, although it was very intense, it was not based on mutual honesty. As he says: "I could not (...) put down the camera and shout You're a monster!" (Oppenheimer, 2013). Although it does not seem like Oppenheimer deliberately set the scene, which can be read as a sign of repentance on Anwar's part, the main protagonist has a tendency to care about his image and select spectacular costumes, which, to the viewer, makes him seem like a natural born actor.

Reminiscing the performed killings, as well as the 'style' and the trendy clothes that made them stand out from the crowd as young gangsters, are evidently pleasurable for Anwar. His behaviour and stories are geared to gain others' admiration or even sympathy. Therefore, it is for every viewer to decide whether they believe Anwar's mental breakdown, whether his behaviour indicates repentance, or whether he is just feeling sorry for himself. Above all, would any repentance change our opinion of him as a person? The film does not have fixed answers to these questions, and attempts to create them seem somewhat abusive towards Oppenheimer's work.

However, this freedom of interpretation given to audiences (and the difficulty it causes), left Oppenheimer exposed to one more charge. Sears (2014) argues that 
audiences most interested in the subject - that is, Indonesian citizens - may read The Act of Killing in a completely different way than Western viewers. The subtle design that forces offenders to admit that they were sadistic and evil and their victims were often innocent may be transparent to intellectuals. For different audiences, however, it may not be clear at all, and the main message they take away from the film may be that the winner - a despicable character like Anwar Congo - ultimately gets to speak. On top of that, an American film director arrive helps the murderers make a film glorifying their crimes. The film does not appear to contain any explicit criticism of the evil it shows. Referring to her "eight or nine" years of studying trauma in Indonesian historical texts, literature, and collective memory,

Sears assesses that Anwar's actions do not reveal that he suffers from deep trauma after what he did. Instead, she states: "I know that Oppenheimer's intentions are far different from what I see as the results, and I do see the benefit of TAOK bringing discussions of the killings out into the public sphere at this time" (Sears, 2014 , p. 206). In Sears' opinion, the film inadvertently maintains the status quo, and instead of triggering discussion that could give victims' a chance to regain their voices, in some ways it promotes a part of the perpetrators' discourse. The judgment of this aspect of the film is similar to her assessment of its actual impact on reality.

Oppenheimer explores the subject further in his next film, The Look of Silence. The film was first screened at the Venice Film Festival in September 2014. Aside from winning five at this festival, it was awarded dozens of other prestigious statuettes and its prominence was almost equal to that of The Act of Killing.

Formally, The Look of Silence is a more conventional film, carrying an equally powerful message. Its main character, Adi, never met his older brother, who was killed in 1965. Half a century later, Adi decides to find and talk to the people responsible for his brother's death. In this way, Oppenheimer completes the picture of the crime by showing the situation from a victims' perspective, rather than the executioners' (as in his first film).

The worldwide publicity gained by these films forced Indonesian authorities to react. Early reactions to the Oscar nominations for The Act of Killing were aimed at cooling emotions and contributed little to the discussion. Recently, however, victims' families and former political prisoners have frequently and loudly spoken about the trauma they survived and their expectations of the Indonesian government. In May 
2016, they demanded that authorities work to identify mass graves. President Joko Widodo pointed the minister responsible for the issue. However, due to resistance from both society and the Indonesian ruling elite, it appears the matter may once again become stuck in a deadlock ("Protect Mass Graves", 2016). This scenario confirms the words of Indonesia's defence minister, who -applauded by an audience of hundreds - claimed that Indonesian communists "deserved to die" ("Defense Minister Ryamizard", 2016). People accused of promoting communism -which remains illegal in Indonesia - were arrested in waves throughout the country.

The issue of Indonesia's genocide was erased particularly effectively from the collective memory of young Indonesians, who often emphasise that Oppenheimer's films helped them realise how painful and cruel the past of their nation. ${ }^{10}$

Although local activities may be incomparable to award-winning films, theatre and art festivals in terms of the scale of the impact, attention should certainly be given to a social project in Bumen village (kampung), Yogyakarta, undertaken by an American activist and researcher, Sharon Kaziuans. The people of Bumen were particularly affected by the wave of anti-communist violence, as 90 per cent of the village's male population was imprisoned due to accusations of communist leanings based on their union membership. ${ }^{11}$ Kaziuans describes the state of affairs, as found in 2010, the year she started her project:

"Under the repressive 31 year Suharto "New Order" regime, Indonesia was inundated with anti-communist propaganda and former members of the PKI and their communities were blacklisted and ostracized. Faced with the stigma of being known as a "black kampung", Kampung Bumen experienced a crisis of identity resulting from its marginalized economic and social status. At the time of the project, it was still taboo to discuss the mass killings and imprisonment of 1965. The goal of this urban and community participatory development project was to help the community of Bumen to reclaim its history from the official narrative, redefine its identity in positive terms, and reinvigorate its rapidly disappearing public spaces" (Kaziunas, 2010: para. 2).

As residents of Bumen did not willingly engage in actions directly commenting on the events of 1965 , the initiator of the project decided to involve them in a series of actions aimed at restoring the positive image of their village, raising their spirits,

\footnotetext{
${ }^{10}$ See, for example: Apriadi Gunawan 2012.

${ }^{11}$ The men were members of The Cooperative of Blek Craftsmen of Kota Gede (Koperasi Pengrajin Blek Kotagede, KPBK), a union for manufacturers of packaging for traditional Indonesian delicacies called krupuk (known as blek).
} 
and returning their pride. In this project, a mural was created on the wall of one building, a pendopo (traditional meeting place for village residents). The entrance gate to the kampung was also rebuilt.

Although it has been almost two decades since the fall of Suharto's regime, Indonesia is still experiencing struggles with different mnemonic actors trying to influence society's collective memory of the events of 1965-1966. Surprisingly, despite the dynamics of the public debate on Indonesia's past, anti-Communist sentiment has been growing. The film Pengkhianatan G30S/PKI is again being used to shape Indonesians' knowledge and opinions of the events. On the initiative of the Indonesian military, screenings of this film have been organized throughout the archipelago as part of the commemoration of the 30 September coup. Only the future will show whether such action will prove effective. However, many commentators have suggested that this method of manipulation cannot be successful again. In an article published in The Jakarta Post, Krismantari (2017) suggests that today's millennials - the main target of these screenings - are active audiences that will compare the film's version with easily accessible internet sources. Moreover, she even suggests that "their various interpretations of the movie could benefit reconciliation efforts, as it would facilitate more dialogue to resolve '1965'" (2017, p. 2).

\section{Conclusion}

It is too early to say whether Krismantari is right, it seems that debate concerning the painful past is gaining momentum. People reluctant to recognise the version of events proposed by artists and activists, as well as by others taking up the subject, will soon be forced to change their attitudes. The complicated process of settling with the traumatic past, once started, is extremely difficult to stop. However, two basic narratives concerning those events still coexist in the Indonesian public space. One speaks of violence against Indonesian communists, the other tries to legitimise it, directing attention to the PKI's alleged violence against the Indonesian State. The aforementioned new wave of Pengkhianatan G30S/PKI screenings, paradoxically, may indicate that the version of events created and promoted by the Orde Baru regime is weakening, or at least its supporters are afraid of losing their power. Otherwise, further action would not be necessary. 
The artistic activities analysed in this paper are just some of the actions undertaken in Indonesia and abroad. Interest in the subject, shown by the media and the academia, is also constantly growing. Considering these factors, one can risk the claim that this crime should not be referred as 'unspoken' or 'forgotten' any longer, although there is still much to say and do.

\section{References}

Anderson, B. (1998), The Spectre of Comparisons: Nationalism, Southeast Asia, and the World, London - New York: Verso. (1973). Petrus Dadi Ratu. New Left Review, vol. 3, 5-15.

Baker, J. (2014). Remembering to forget, Critical Asian Studies, 1(46), 150-156.

Bonczol, Ł. (2012). Zrozumieć Indonezję. Nowy Ład generała Suharto, Warsaw: Dialog. Chomsky, N., \& E. Herman. (1988), Manufacturing Consent. The Political Economy of the Mass Media. New York: Pantheon Books.

Cribb, R. (2013) An Act of Manipulation? Retrieved from http://www.insideindonesia.org/weekly-articles/review-an-act-ofmanipulation (10 August, 2014). . (2004). The Indonesian Massacres, in Totten, S., W. Parson, I.W. Charny (Ed.), Century of Genocide. (pp. 233-262). London - New York: Routledge. . (2001). How many deaths? Problems in the statistics of massacre in Indonesia (1965-1966) and East Timor (1975-1980), in Wessel, I., G. Wimhoefer, (Ed.), Violence in Indonesia. (pp. 82-98). Hamburg: Abera.

Cribb, R., \& A. Kahin. (2004). Historical Dictionary of Indonesia, 2nd edn., Lanham Toronto - Oxford: The Scarecrow Press, Inc.

Defense Minister Ryamizard says suspected communists "deserved to die". (2016, June 3). Retrieved from http://jakarta.coconuts.co/2016/06/03/defenseminister-ryamizard-says-suspected-communists-deserved-die (20 September, 2016).

Dwyer, L.K. (2014). Picturing Violence: Anti-Politics and The Act of Killing, Critical Asian Studies, 1 (46), 183-188.

Gallately, R., \& Kierman, B. (Eds.). (2003). The Specter of Genocide. Mass Murder in Historical Perspective. New York: Cambridge University Press. 
Gunawan, A. (2012). Film praised by victims, shocks students. Retrieved from http://thejakartapost.com/news/2012/12/13/film-praised-victims-shocksstudents.html (10 April, 2014).

Heryanto, A. (2005). State Terrorism and Political Identity in Indonesia, New York: Routledge.

Kaziuans, S. (2010). Yayasan Pondok Rakyat. Retrieved from http://sharonkaziunas.com/index.html/bumen.html (20 September, 2016).

Krismantari, I. (2017, September 29). Propaganda déjà vu? Let's learn from millennials, The Jakarta Post, 2.

Lis, M. (2015). Rok 1965 w Indonezji w spektaklach Papermoon Puppet Theatre z Yogyakarty i filmie Scena zbrodni Joshuy Oppenheimera. Studia Azjatystyczne, 1, 64-76.

Mortimer, R. (2006). Indonesian Communism Under Sukarno: Ideology and Politics, 1959-1965. Jakarta: Equinox Publishing.

Protect Mass Graves of 1965-66 Massacres. (2016, May 22). Retrieved from https://www.hrw.org/news/2016/05/22/indonesia-protect-mass-graves1965-66-massacres (20 September, 2016).

Roosa, J. (2010, January 24). Dictionary of a Disaster. Inside Indonesia. Retrieved from http://www.insideindonesia.org/feature-editions/dictionary-of-adisaster (19 June, 2015).

Sears, L.J. (2014). Heroes as killers or Killers as Heroes? Critical Asian Studies, 1 (46), 204-207.

Wandita, G. (2014). PREMAN NATION: Watching The Act of Killing in Indonesia. Critical Asian Studies, 1 (46), 167-170.

Wardaya, F. X. (2001). A Cold War shadow: United States policy toward Indonesia, 1953-1963. 